\title{
Perbandingan Karakteristik Kinerja Sudu Turbin Setengah Lingkaran dengan Turbin NEST-LIE pada Prototipe Pembangkit Listrik Tenaga Mikro Hidro
}

\author{
Nia Paramitha ${ }^{1}$, Lie Jasa ${ }^{2}$, I Gusti Ngurah Janardana ${ }^{3}$ \\ [Submission: 28-02-2021, Accepted: 08-03-2021]
}

\begin{abstract}
Through this research, the writer wants to make a comparison of the performance of two different types of turbines by changing several parameters. The turbines that will be compared are the turbine with semicircular blades and the NEST-LIE turbine. The NEST-LIE turbine is a turbine designed with a semicircular blade on the side of the circle, with 16 blades and a turbine diameter of $50 \mathrm{~cm}$. Comparison of turbine performance as intended in this study aims to determine the performance characteristics of the turbine based on the output power on predetermined parameters. In this research, the parameters to be used are nozzle angle $0^{\circ}, 5^{\circ}, 10^{\circ}, 15^{\circ}, 20^{\circ}$, and nozzle position at angles of $0^{0}, 15^{\circ}, 30^{\circ}$, and $45^{\circ}$. Based on the research results, the semicircular turbine produces the highest rotation speed at $45^{\circ}$ nozzle positions and angles nozzle $10^{\circ}$ with an output power of 0.0213 VA. Meanwhile, the NEST-LIE turbine produces the highest rotation speed at nozzle position $45^{\circ}$ and nozzle angle $5^{0}$ with an output power of $0.1802 \mathrm{VA}$. It can be concluded that the NEST LIE turbine has better characteristics than the semicircular turbine because it produces a greater output power under optimal conditions.
\end{abstract}

Keywords - Hydropower, Water turbine, Nozzle angle, Nozzle position

Intisari- Melalui penelitian ini penulis ingin melakukan perbandingan terhadap kinerja dua jenis turbin yang berbeda dengan mengubah beberapa parameter. Turbin yang akan dibandingkan adalah turbin dengan sudu setengah lingkaran dan turbin NEST-LIE. Turbin NEST-LIE merupakan turbin yang dirancang dengan sudu berbentuk setengah lingkaran yang berada pada sisi lingkaran, dengan jumlah sudu sebanyak 16 buah, dan diameter turbin sebesar $50 \mathrm{~cm}$. Perbandingan kinerja turbin yang dimaksudkan pada penelitian ini bertujuan untuk mengetahui karakteristik kinerja turbin berdasarkan daya output pada parameter yang telah ditentukan. Pada penelitian ini, parameter yang akan digunakan adalah sudut nozzle $0^{0}, 5^{0}$, $10^{0}, 15^{0}, 20^{\circ}$ dan posisi nozzle pada sudut $0^{0}, 15^{\circ}, 30^{\circ}$ dan $45^{\circ}$. Berdasarkan hasil penelitian, turbin setengah lingkaran menghasilkan kecepatan putaran tertinggi pada posisi nozzle $45^{\circ}$ dan sudut nozzle $10^{\circ}$ dengan daya output sebesar 0.0213 VA.

${ }^{1}$ Mahasiswa Program Studi Teknik Elektro Fakultas Teknik Universitas Udayana, Gg Taman Mangga, Jimbaran, Badung, Bali 80361 INDONESIA, (Tlp: 082236255181; e-mail: niaparamitha45@gmail.com)

${ }^{3}$ Dosen Program Studi Teknik Elektro Fakultas Teknik Universitas Udayana, Jln. Jalan Kampus Bukit Jimbaran 80361 INDONESIA (telp: 0361-703315; e-mail: ${ }^{2}$ liejasa@unud.ac.id, 3 email : janardana@ee.unud.ac.id)

Nia Paramitha : Perbandingan Karakteristik Kinerja Sudu.........
Sedangkan pada turbin NEST-LIE menghasilkan kecepatan putaran tertinggi di posisi nozzle $45^{\circ}$ dan sudut nozzle $5^{\circ}$ dengan daya output sebesar 0.1802 VA. Dapat disimpulkan bahwa turbin NEST LIE memiliki karakteristik yang lebih baik dibandingkan dengan turbin setengah lingkaran karena menghasilkan daya output yang lebih besar pada kondisi optimal.

Kata Kunci-PLTMH, Turbin Air, Sudut Nozzle, Posisi Nozzle.

\section{PENDAHULUAN}

Indonesia berada di wilayah tropis yang memiliki musim hujan dan musim kemarau. Pada saat memasuki musim hujan, aliran air pada sungai-sungai yang ada sangat berlimpah sehingga apabila dapat dimanfaatkan dengan baik akan dapat menghasilkan potensi besar untuk dijadikan sumber pembagkitan listrik. Potensi pembangkitan listrik tenaga air dapat mencapai 208 MW dan potensi pembangkitan listrik dari tenaga mikrohidro dapat mencapai $15 \mathrm{MW}$ dalam kondisi ideal [1].

Pembangkit listrik tenaga mikro hidro (PLTMH) adalah suatu jenis pembangkit tenaga air berkapasitas kecil yang biasanya dibangun di daerah yang memiliki potensi pembangkitan listrik tenaga air dalam skala kecil. Pemilihan lokasi dari pemasangan PLTMH ditentukan oleh potensi air yang jatuh atau air terjun (waterfall). Berdasarkan head atau ketinggian air yang jatuh, maka turbin dapat dikatagorikan menjadi 3 jenis head yaitu rendah, sedang, dan tinggi. Parameter desain yang berpengaruh terhadap pengoperasian PLTMH adalah jumlah sudu, bentuk sudu, diameter turbin, rotasi per menit, lebar turbin, sudut nozzle, dan posisi nozzle [2].

Berikut merupakan beberapa penelitian terkait dengan turbin air. Penelitian tentang pemanfaatan saluran irigasi menyatakan bahwa turbin dengan diameter $40 \mathrm{~cm}$, lebar 30 $\mathrm{cm}$, jumlah sudu 16, mampu menghasilkan kecepatan pada poros turbin sebesar $130 \mathrm{rpm}$ [3]. Kemudian penelitian tentang pengaruh model sudu terhadap turbin. Pada penelitian ini sudu jenis segitiga memperoleh hasil pengukuran terbaik pada sudut nozzle $30^{\circ}$ dengan $151,6 \mathrm{rpm}$ dan torsi $0,017 \mathrm{Nm}$. Sedangkan sudu setengah lingkaran mendapatkan luasan volume debit air terbaik sebesar 3,19 liter [4].

Pada penelitian yang menganalisis perbandingan segitiga kerja. Pada sudu turbin setengah lingkaran, luas segitiga kerja menghasilkan rpm yang makin besar, seperti pada saat sudut posisi nozzle $0^{0}$ dan sudut nozzle $25^{\circ}$ dengan luasan segitiga kerja 360,36 $\mathrm{cm}^{2}$ menghasilkan $216 \mathrm{rpm}$ pada putaran kincir dan $1626 \mathrm{rpm}$ pada putaran generator, dan pada saat sudut p-ISSN:1693 - 2951; e-ISSN: 2503-2372 
posisi nozzle $15^{0}$ dan sudut nozzle $20^{\circ}$ dengan luasan segitiga kerja $264.27 \mathrm{~cm}^{2}$ menghasilkan $221 \mathrm{rpm}$ pada putaran kincir dan $1711 \mathrm{rpm}$ pada putaran generator, sedangkan pada saat sudut posisi nozzle $30^{\circ}$ dan sudut nozzle $10^{\circ}$ luas segitiga kerjanya $134.37 \mathrm{~cm}^{2}$ dan menghasilkan $173 \mathrm{rpm}$ pada putaran kincir dan $1307 \mathrm{rpm}$ pada putaran generator [5].

Berikut merupakan penelitan berdasarkan jenis-jenis turbin air. Menurut penelitian yang mendesain turbin model NESTLIE. Didapatkan hasil bahwa turbin NEST-LIE saat berada pada tekanan 28 Psi menghasilkan kecepatan sebesar 157,2 $231,1 \mathrm{rpm}$, dimana posisi nozzel $0^{\circ}-5^{\circ}$ dan sudut nozzel $22,5^{\circ}$ dengan kecepatan tertinggi [6]. Berdasarkan penelitian tentang kinerja turbin setengah lingkaran dengan memvariasikan jumlah sudu. Penelitian ini menghasilkan bahwa kinerja paling efektif mendapatkan torsi $0,14 \mathrm{kgm}$, daya 1,479 watt, dan efisiensi $8,03 \%$ pada turbin dengan 10 sudu [7].

Pada penelitian menggunakaan kincir Overshoot Wheel. Pengukuran yang dilakukan pada pemodelan PLTMH, mencakup tekanan air, debit air, putaran generator, putaran kincir, arus, tegangan, daya, torsi, dan efisiensi. Parameterparameter tersebut diukur dengan cara merubah posisi sudut nozzle $0^{0}$ sampai $40^{\circ}$. Maka dari itu, memperoleh hasil pengukuran tertinggi dengan daya output 0,153 watt, nilai torsi $0,012 \mathrm{Nm}$ dan efisiensi sebesar $25,5 \%$ pada sudut nozzle $30^{0}$ [8].

Penelitian terbaru yang menggunakan turbin PELTON seperti pada penelitian tentang rancang bangun prototype PLTMH turbin PELTON. Menyatakan bahwa prototipe ini mampu menghasilkan debit air sebesar 4,5 L/s, daya sebesar 9,809 W dan torsi sebesar 0,26 $\mathrm{Nm}$ sehingga memiliki efisiensi sebesar $1,48 \%$ [9]. Penelitian yang meneliti turbin PELTON tentang pengaruh tekanan air dan sudut nozzle. Memperoleh hasil bahwa output maksimum diperoleh saat tekanan air 25 psi dengan sudut nozzle $90^{\circ}$ dengan kecepatan turbin 326 rpm saat dikopel generator. Daya yang dihasilkan sebesar 30,96 Watt, torsi 0,98 Nm, dan Efisiensi 3,91\% [10].

Penelitian terbaru terkait PLTMH seperti pada penelitian tentang karakteristik kinerja turbin SNAIL-LIE. Didapatkan hasil bahwa besarnya sudut lengan nozzle juga dapat mempercepat putaran turbin dan generator, maka berbanding lurus juga dengan arus dan tegangan yang dihasilkan [11]. Pada Penelitian tentang karakteristik dari turbin SNAIL-LIE yang memiliki 4 snail dan 8 snail. Menyatakan bahwa output tertinggi pada posisi nozzle $0^{\circ}$ dan sudut nozzle $20^{\circ}$ menggunakan 8 snail menghasilkan putaran turbin 166,9 rpm, putaran generator $1086,8 \mathrm{rpm}$, tegangan generator 0,707 volt, daya generator 0,189 watt, dan torsi sebesar $0,01 \mathrm{Nm}$, serta efisiensi 20,8\% [12]. Penelitian terkait turbin NEST-LIE tentang karakteristik kinerja turbin NEST-LIE. Didapatkan hasil bahwa turbin NEST-LIE menghasilkan nilai torsi maksimum $0,0076 \mathrm{Nm}$ pada posisi nozzle $45^{\circ}$ dan sudut nozzle $10^{0}[13]$.

Pada penelitian - penelitian terkait PLTMH yang telah banyak dilakukan menunjukan bahwa perubahan parameter yang paling banyak ditemukan dalam pengaruhnya terhadap daya output dari model pembangkit mikro hidro adalah pada perubahan sudut nozzle, sudut sudu, jumlah sudu, diameter turbin, dan lebar turbin. Perubahan parameter yang masih jarang dijumpai pada penelitian PLTMH yaitu perubahan debit air (Q), tekanan air, kecepatan aliran air (v), dan ketinggian jatuh air $(\mathrm{H})$.

Melalui penelitian ini penulis ingin melakukan perbandingan terhadap kinerja dua jenis turbin yang berbeda dengan mengubah beberapa parameter. Perbandingan ini dilakukan untuk mengetahui karakteristik kinerja dari kedua jenis turbin berdasarkan kecepatan putaran turbin dan generator, nilai torsi, dan daya output yang dihasilkan pada parameter yang telah ditentukan. Turbin yang akan dibandingkan adalah turbin dengan sudu setengah lingkaran dan turbin NEST-LIE. Turbin NEST LIE merupakan prototype turbin yang saat ini sedang dikembangkan di Laboratorium Konversi Energi dan Workshop Program Studi Teknik Elektro Fakultas Teknik Universitas Udayana. Cara kerja prototype PLTMH ini diawali dengan pompa yang mengangkat air di dalam bak, kemudian air mengalir melalui pipa sehingga sampai ke sudu kincir dan memutar kincir. Perputaran kincir ini menghasilkan energi mekanik dan terhubung dengan pulley kincir pada sebuah poros. Pulley kincir dihubungkan dengan pulley generator menggunakan sebuah belt. Kincir yang berputar akan memutar generator karena kedua pulley yang saling terhubung. Energi mekanik dikonversi menjadi energi listrik menggunakan generator.

Perbandingan kinerja turbin yang dimaksudkan pada penelitian ini adalah perbandingan daya output dan efisiensi turbin. Parameter yang akan digunakan pada penelitian ini adalah sudut nozzle $0^{\circ}, 5^{\circ}, 10^{\circ}, 15^{\circ}, 20^{\circ}$, dan posisi nozzle pada sudut $0^{0}, 15^{\circ}, 30^{\circ}$ dan $45^{\circ}$. Karakteristik kinerja turbin yang nantinya akan diukur adalah besarnya kecepatan sudut (rpm) masing-masing turbin dan besarnya daya output turbin, sehingga nantinya perbandingan kinerja turbin dapat dibandingkan melalui nilai-nilai yang telah diukur tersebut. Berdasarkan penjelasan tersebut maka dalam penelitian ini akan meneliti mengenai perbandingan karakteristik kinerja turbin setengah lingkaran dan turbin NEST-LIE pada parameter sudut nozzle dan posisi nozzle yang telah ditentukan.

\section{TINJAUAN PUSTAKA}

\section{A. Teori Aliran Air}

Air mengalir memiliki energi yang dapat digunakan untuk menggerakan turbin, maka dari itu pusat-pusat pembangkit listrik tenaga air dibangun di daerah aliran sungai dan di daerah pegunungan. Pusat tenaga air dikatagorikan kedalam dua golongan, yaitu pusat tenaga air tekanan rendah dan tekanan tinggi. Air dialirkan menuju host power dengan menggunakan pipa yang dibangun di bagian bawah bendungan dan di dalam bangunan dipasang sebuah nozzle untuk menyemburkan air ke luar dan memutar roda turbin, kemudian air dialirkan kembali ke sungai. Selisih tinggi permukaan air atas dan bawah terdapat tinggi air jatuh yang dikenal dengan ketinggian [14].

\section{B. Energi Potensial}

Energi potensial merupakan energi yang terjadi akibat adanya beda ketinggian atau beda potensial. Semakin tinggi asal sumber air atau semakin tinggi jatuhnya air, maka semakin besar energi yang dihasilkan.

$$
E p=m \cdot g \cdot h
$$


Dimana EP adalah Energi potensial dalam satuan Joule, $\mathrm{m}$ adalah massa dalam satuan $(\mathrm{kg})$, g adalah gravitasi dengan konstanta $9,8 \mathrm{~kg} / \mathrm{m}^{2}$ dan $\mathrm{h}$ adalah ketinggian atau head dalam satuan $(\mathrm{m})$.

\section{Daya Turbin}

Head dan debit air mempengaruhi besaran tenaga air yang tersedia di suatu sumber air. Energi potensial air merupakan keseluruhan air yang tersedia pada suatu reservoir air. Daya merupakan energi tiap satuan waktu $\left(\frac{E}{t}\right)$, sehingga peras`maan (1) dapat dinyatakan sebagai:

$$
\frac{E}{t}=\frac{m}{t} g h
$$

Dengan menstubtitusikan $\mathrm{P}$ terhadap $\left(\frac{E}{t}\right)$ dan menstubtitusikan $\rho Q$ terhadap $\left(\frac{m}{t}\right)$ maka [15]:

$$
P=p Q g h
$$

Daya yang dihasilkan turbin dihitung dengan menggunakan persamaan berikut bila diperhitungkan efisiensi turbin maka dapat dituliskan pada persamaan dibawah ini

$$
P=\eta t \cdot \gamma Q H
$$

Dimana $\mathrm{P}$ adalah daya yang dihasilkan turbin dalam satuan $(\mathrm{kW}), \eta \mathrm{t}$ adalah efisiensi turbin, $\gamma$ adalah berat jenis air $(9.18$ $\left.\mathrm{kN} / \mathrm{m}^{3}\right)$, Q adalah debit air $\left(\mathrm{m}^{3} / \mathrm{s}\right), \mathrm{H}$ adalah beda ketinggian bersih [14].

\section{Macam-macam Parameter Sudu Turbin}

\section{1) Sudu Turbin Setengah Lingkaran}

Turbin dengan sudu setengah lingkaran terdiri dari dua bagian utama yaitu nozzle dan runner. Nozzle adalah bagian yang tidak bergerak sedangkan runner adalah bagian yang bergerak. Runner dibuat dari dua buah piringan sejajar yang digabungkan oleh sederetan sudu melengkung di bagian tepi. [14].

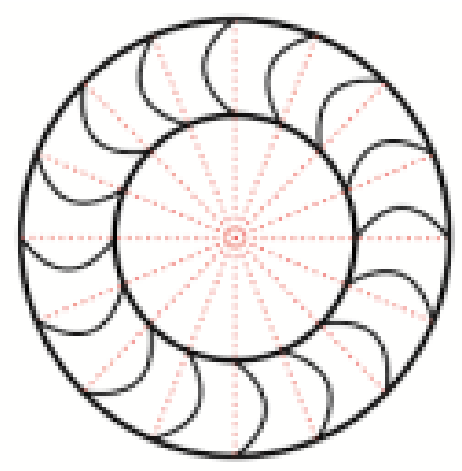

Gambar 1 Sudu Turbin Setengah Lingkaran

\section{2) Sudu Turbin NEST-LIE}

Nia Paramitha : Perbandingan Karakteristik Kinerja Sudu.........
Sudu turbin dibuat dari bahan akrilik, dirancang dengan sudu berbentuk setengah lingkaran, dengan jumlah sudu sebanyak 16 buah, dan diameter turbin sebesar $50 \mathrm{~cm}$. NESTLIE dibuat dalam bentuk lingkaran yang berada pada sisi lingkaran bagian dalam yang ada pada dasar dari posisi sudu [14].

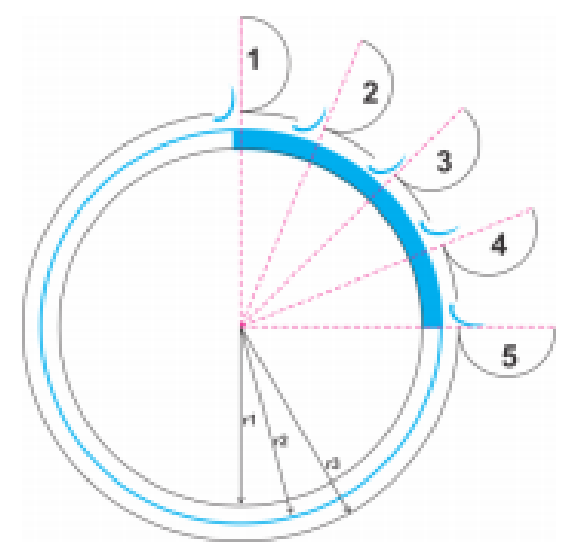

Gambar 2 Sudu Turbin NEST-LIE Setengah Lingkaran

\section{E. Pembangkit Tenaga Listrik Tenaga Mikro Hidro}

Pembangkit listrik tenaga mikro hidro atau PLTMH merupakan pembangkit listrik tenaga air berskala kecil dengan rentang kapasitas $5 \mathrm{~kW}$ sampai dengan $1 \mathrm{MW}$ per unit. Penggolongan pembangkit listrik tenaga air skala kecil dibedakan menjadi 3, yaitu Mini hidro berkapasitas $100 \mathrm{~kW}$ sampai dengan $1 \mathrm{MW}$, Mikro hidro dengan kapasitas 1 - 100 $\mathrm{kW}$, dan Piko hidro dengan kapasitas kurang dari $1 \mathrm{~kW}$ [16].

PLTMH memanfaatkan beda ketinggian atau selisih head dan jumlah debit air tiap detik pada aliran air atau sungai. Air mengalir melalui intake menuju penstock melalui saluran, kemudian memutar turbin untuk menghasilkan energi putar mekanik. Turbin air yang berputar akan memutar generator dan menghasilkan energi listrik [17].

\section{F. Bagian-bagian Pembangkit Listrik Tenaga Mikro Hidro \\ 1) Pipa Pesat (penstock)}

Pipa pesat atau penstock adalah pipa untuk menyalurkan air dari atas ke bawah dan mengarahkan aliran air ke turbin [18].

\section{2) Governor}

Governor digunakan untuk mengatur masuknya aliran air dari penstock menuju turbin. Model governor dibedakan kedalam beberapa bentuk, seperti governor mekanik, hidrolik mekanik dan elektro hidrolik [2].

\section{3) Turbin Air}

Turbin air adalah turbin yang menggunakan air sebagai fluida kerja atau penggerak turbin secara mekanis dengan memanfaatkan aliran air yang mengalir dari tempat tinggi ke tempat yang lebih rendah [19].

p-ISSN:1693 - 2951; e-ISSN: 2503-2372 
4) Nozzle

Nozzle adalah alat untuk mengendalikan arah aliran fluida untuk meningkatkan kecepatan air saat keluar dari pipa [14].

\section{5) Generator}

Generator adalah alat untuk mengkonversi energi putar mekanis menjadi energi listrik. Medan magnet yang diputar pada rotor menimbulkan medan magnet imbas pada sisi stator. Medan magnet yang terjadi pada sisi stator dengan pola-pola tertentu akan menghasilkan arus listrik [2].

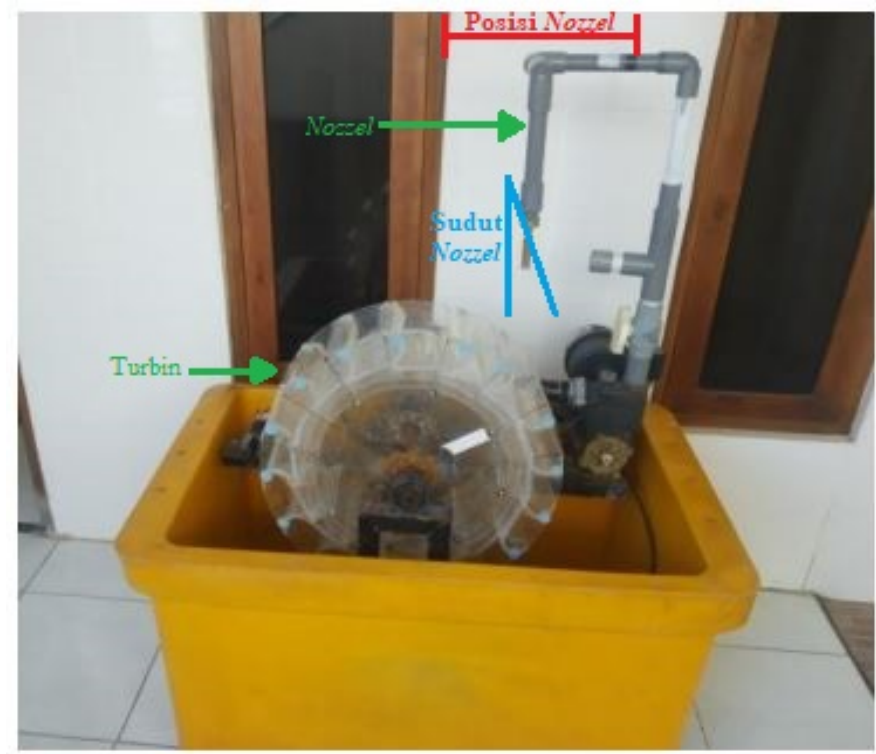

Gambar 3 Komponen Komponen Prototipe PLTMH

\section{G. Teori Dasar Alat Ukur}

\section{1) Tachometer}

Tachometer merupakan sebuah alat pengukur kecepatan putar atau rotasi dari sebuah objek.

\section{2) Multimeter}

Multimeter atau multitester adalah alat ukur listrik, untuk mengukur tegangan, arus, maupun hambatan listrik.

\section{3) Manometer}

Manometer adalah alat yang digunakan untuk mengukur tingkat tekanan.

\section{H. Perhitungan Karakteristik Turbin Secara Matematis}

\section{1) Rasio Kecepatan}

Rasio Kecepatan merupakan perbandingan antara kecepatan keliling linier turbin pada ujung diameter nominalnya dibagi dengan kecepatan teoritis air melalui curat dengan tinggi terjun sama dengan ( $\mathrm{H}$ netto) yang bekerja pada turbin. Rasio kecepatan dapat dirumuskan sebagai berikut [20]:

$$
\emptyset=\frac{N D}{94,6 \sqrt{H}}
$$

Dengan $\mathrm{N}$ merupakan putaran turbin dalam rpm, D adalah diameter turbin $(\mathrm{m})$, dan $\mathrm{H}$ adalah tinggi terjun neto/effektif (m).

\section{2) Kecepatan Satuan $(\mathrm{Nu})$}

Kecepatan Satuan $(\mathrm{Nu})$ merupakan kecepatan putar turbin yang mempunyai diameter (D) dalam suatu satuan panjang dan bekerja pada tinggi terjun (H netto) [20].

$$
N u=\frac{N D}{\sqrt{H}}
$$

\section{3) Debit Satuan (Qu)}

Debit yang masuk turbin secara teoritis dapat diasumsikan sebagai debit yang melalui suatu curat dengan tinggi terjun sama dengan tinggi terjun ( $\mathrm{H}$ netto) yang bekerja pada turbin. Oleh karena itu debit yang melalui turbin dapat dinyatakan sebagai berikut [20].

$$
Q=C D^{2} \sqrt{H}
$$

Debit satuan $(\mathrm{Qu})$ adalah debit turbin yang mempunyai diameter (D) dan bekerja pada tinggi terjun ( $\mathrm{H}$ netto) yang dapat dirumuskan sebagai berikut [20]:

$$
Q_{u}=\frac{Q}{D^{2} \sqrt{H}}
$$

\section{4) Daya Satuan $(P u)$}

Daya satuan $(\mathrm{Pu})$ adalah daya turbin yang mempunyai diameter (D) satuan panjang dan bekerja pada tinggi terjun $(\mathrm{H}$ netto) satu satuan panjang dan dapat didefinisikan sebagai berikut [20]:

$$
P_{u}=\frac{P}{D^{2} H^{3 / 2}}
$$

\section{5) Kecepatan Spesifik (Ns)}

Kecepatan spesifik (Ns) adalah kecepatan putar turbin yang menghasilkan daya sebesar satu satuan daya pada tinggi terjun ( $\mathrm{H}$ netto). Kecepatan spesifik dapat dihitung dengan persamaan berikut [20] :

$$
N_{s}=\frac{N \sqrt{P}}{H^{5 / 4}}
$$

Sementara untuk kecepatan putar generator (N) dalam satuan rpm dapat dihitung menggunakan persamaan berikut [20]:

$$
N=\frac{p}{2 \pi T}
$$

Dimana P merupakan daya generator dengan satuan Watt (W) dan T merupakan besarnya torsi generator dengan satuan Newton meter $(\mathrm{Nm})$. 


\section{METODE PENELITIAN}

Penelitian ini dilaksanakan di Laboratorium Konversi Energi dan Workshop Program Studi Teknik Elektro, Fakultas Teknik, Universitas Udayana yang berlokasi di Kampus Bukit Jimbaran, Bali pada bulan Maret 2020. Secara sistematik tahapan penelitian dapat dilihat seperti pada Gambar 4.

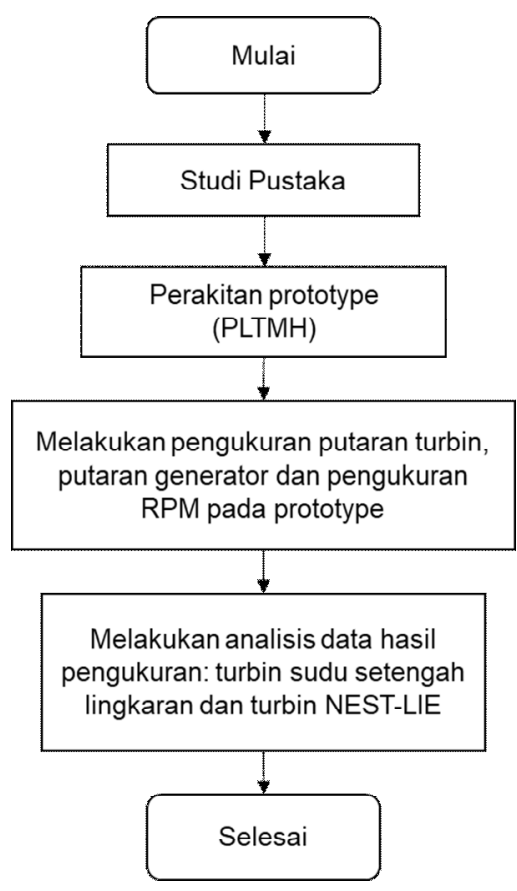

Gambar 4 Sistematik Tahapan Penelitian

Analisis perbandingan karakteristik kinerja turbin sudu setengah lingkaran dan jenis turbin NEST-LIE pada pemodelan PLTMH dapat dijabarkan sebagai berikut:

1. Melakukan studi analisis mencari referensi, buku, jurnal atau artikel terkait dengan PLTMH

2. Proses perakitan pemodelan PLTMH dalam penelitian ini dapat dijabarkan sebagai berikut; merakit kincir dan pompa, merakit instalasi perpipaan, memasang generator, merakit pulley kincir dan pulley generator.

3. Dilakukan uji coba dan pengambilan data pada kedua jenis turbin yang dapat dijabarkan sebagai berikut : Pengambilan data dilakukan dengan menetapkan titik jatuh air pada posisi sudut nozzle $0^{0}, 5^{0}, 10^{\circ}, 15^{\circ}, 20^{\circ}$, dan posisi nozzle pada sudut $0^{\circ}, 15^{\circ}, 30^{\circ}$ dan $45^{\circ}$. Model turbin sebanyak 2 jenis, yaitu sudu setengah lingkaran, dan jenis turbin NEST-LIE karena dalam penelitian ini bertujuan untuk menyempurnakan prototipe PLTMH. Pengukuran yang difokuskan untuk mengetahui kecepatan putaran turbin, kecepatan putaran generator, dan menentukan RPM tertinggi yang akan dibandingkan dan tegangan output dari masing-masing sudu turbin.

4. Analisis data hasil pengukuran untuk mendapatkan parameter - parameter turbin yang optimal setelah mendapatkan hasil pengukuran kecepatan putaran turbin, kecepatan putaran generator nilai rpm yang optimal dan

Nia Paramitha : Perbandingan Karakteristik Kinerja Sudu......... tegangan output dari kedua jenis turbin, maka dapat dibandingkan karakteristik kinerja dari kedua jenis turbin.

\section{HASIL DAN PEMBAHASAN}

\section{A. Analisis Hasil Pengukuran Kecepatan Putaran Turbin}

Dan Generator Turbin Setengah Lingkaran

Hasil pengukuran menunjukan pengaruh peningkatan kecepatan putaran baik pada generator maupun turbin akan bertambah besar bersesuaian dengan penambahan besar sudut nozzle.

Analisa pada hasil pengukuran kecepatan genartor dan turbin setangah lingkaran dilakukan berdasarkan beberapa parameter yaitu posisi nozzle, sudut nozzle dan besarnya kecapatan putaran dalam satuan rpm yang dihasilkan. Analisa hasil pengukuran dijabarkan sebagai berikut :

1. Pada Posisi $0^{\circ}$

Kecepatan putaran generator dan turbin paling tinggi adalah pada sudut nozzle $20^{\circ}$ dimana kecepatan generator adalah sebesar 659,2 rpm dan kecepatan putaran turbin adalah sebesar $138 \mathrm{rpm}$.

TABEL 1

PENGUKuRAn Kecepatan Putaran TuRbin Dan Generator Turbin SETENGAH LINGKARAN

\begin{tabular}{|c|c|c|c|}
\hline $\begin{array}{l}\text { Poisi } \\
\text { Nozzle }\end{array}$ & $\begin{array}{l}\text { Sudut } \\
\text { Nozzle }\end{array}$ & $\begin{array}{c}\text { Kecepatan Kincir } \\
\text { (Rad/Minute) }\end{array}$ & $\begin{array}{c}\text { Kecepatan Generator } \\
\text { (Rad/Minute) }\end{array}$ \\
\hline \multirow{5}{*}{$0^{\circ}$} & $0^{\circ}$ & 17 & 107.8 \\
\hline & $5^{\circ}$ & 43.8 & 261.2 \\
\hline & $10^{\circ}$ & 63.8 & 337 \\
\hline & $15^{\circ}$ & 93.2 & 442.2 \\
\hline & $20^{\circ}$ & 138.6 & 659.2 \\
\hline \multirow{4}{*}{$15^{\circ}$} & $0^{\circ}$ & 46.8 & 251.4 \\
\hline & $5^{\circ}$ & 77 & 473.2 \\
\hline & $10^{\circ}$ & 130.2 & 661 \\
\hline & $15^{\circ}$ & 155 & 710.8 \\
\hline \multirow{3}{*}{$30^{\circ}$} & $0^{\circ}$ & 108.2 & 362.4 \\
\hline & $5^{\circ}$ & 158.8 & 731 \\
\hline & $10^{\circ}$ & 123.2 & 730.6 \\
\hline \multirow{3}{*}{$45^{\circ}$} & $0^{\circ}$ & 75.2 & 453.6 \\
\hline & $5^{\circ}$ & 115.4 & 556 \\
\hline & $10^{\circ}$ & 168.6 & 751.2 \\
\hline
\end{tabular}

\section{Posisi nozzle $15^{\circ}$}

Kecepatan putaran generator dan turbin paling tinggi adalah pada sudut nozzle $15^{0}$ dimana kecepatan generator adalah sebesar 710,8 rpm dan kecepatan putaran turbin adalah sebesar $155 \mathrm{rpm}$.

3. Posisi nozzle $30^{\circ}$

Kecepatan putaran generator dan turbin paling tinggi adalah pada sudut nozzle $5^{0}$ dimana kecepatan

p-ISSN:1693 - 2951; e-ISSN: 2503-2372 
generator adalah sebesar $730 \mathrm{rpm}$ dan kecepatan putaran turbin adalah sebesar $158,8 \mathrm{rpm}$.

\section{Posisi nozzle $45^{\circ}$}

Kecepatan putaran generator dan turbin paling tinggi adalah pada sudut nozzle $10^{\circ}$ dimana kecepatan generator adalah sebesar 751,2 rpm dan kecepatan putaran turbin adalah sebesar 168,6 rpm.

\section{B. Analisis Hasil Pengukuran Kecepatan Putaran Turbin} Dan Generator Turbin NEST LIE

Hasil pengukuran menunjukan pengaruh peningkatan kecepatan putaran baik pada generator maupun turbin akan bertambah besar bersesuaian dengan penambahan besar sudut nozzle.

TABEL 2

Pengukuran Kecepatan Putaran Turbin Dan Generator Turbin NEST LIE

\begin{tabular}{|c|c|c|c|}
\hline $\begin{array}{l}\text { Poisi } \\
\text { Nozzle }\end{array}$ & $\begin{array}{l}\text { Sudut } \\
\text { Nozzle }\end{array}$ & $\begin{array}{c}\text { Kecepatan Kincir } \\
\text { (Rad/Minute) }\end{array}$ & $\begin{array}{c}\text { Kecepatan Generator } \\
\text { (Rad/Minute) }\end{array}$ \\
\hline \multirow{5}{*}{$0^{\circ}$} & $0^{\circ}$ & 23.6 & 87.2 \\
\hline & $5^{\circ}$ & 30.8 & 174 \\
\hline & $10^{\circ}$ & 61.2 & 274.8 \\
\hline & $15^{\circ}$ & 77.4 & 318.6 \\
\hline & $20^{\circ}$ & 115.2 & 404,5 \\
\hline \multirow{4}{*}{$15^{\circ}$} & $0^{\circ}$ & 45.4 & 227.6 \\
\hline & $5^{\circ}$ & 52.1 & 319.8 \\
\hline & $10^{\circ}$ & 157.125 & 751 \\
\hline & $15^{\circ}$ & 144,4 & 471,6 \\
\hline \multirow{3}{*}{$30^{\circ}$} & $0^{\circ}$ & 120.67 & 363 \\
\hline & $5^{\circ}$ & 146.80 & 522.6 \\
\hline & $10^{\circ}$ & 327,8 & 1291.4 \\
\hline \multirow{3}{*}{$45^{\circ}$} & $0^{\circ}$ & 111.2 & 516.2 \\
\hline & $5^{\circ}$ & 342,4 & 1349 \\
\hline & $10^{\circ}$ & 290,8 & 942,2 \\
\hline
\end{tabular}

Analisa pada hasil pengukuran kecepatan genartor dan turbin NEST-LIE dilakukan berdasarkan beberapa parameter yaitu posisi nozzle, sudut nozzle dan besarnya kecapatan putaran dalam satuan rpm yang dihasilkan. Analisa hasil pengukuran dijabarkan sebagai berikut :

1. Posisi Nozzle $0^{\circ}$

Kecepatan putaran generator dan turbin paling tinggi adalah pada sudut nozzle $20^{\circ}$ dimana kecepatan generator adalah sebesar 404,5 rpm dan kecepatan putaran turbin adalah sebesar 115,2 rpm.

2. Posisi Nozzle $15^{\circ}$

Kecepatan putaran generator dan turbin paling tinggi adalah pada sudut nozzle $10^{0}$ dimana kecepatan generator adalah sebesar $551 \mathrm{rpm}$ dan kecepatan putaran turbin adalah sebesar $157,1 \mathrm{rpm}$.

3. Posisi Nozzle $30^{\circ}$

Kecepatan putaran generator dan turbin paling tinggi adalah pada sudut nozzle $10^{0}$ dimana kecepatan generator adalah sebesar 1291,4 rpm dan kecepatan putaran turbin adalah sebesar $327 ., 8 \mathrm{rpm}$.

\section{Posisi Nozzle $45^{\circ}$}

Kecepatan putaran generator dan turbin paling tinggi adalah pada sudut nozzle $5^{0}$ dimana kecepatan generator adalah sebesar $1349 \mathrm{rpm}$ dan kecepatan putaran turbin adalah sebesar 342,4 rpm.

\section{Pengukuran Tegangan dan arus Generator dengan pembebanan lampu 2,5 Watt}

Pengukuran tegangan pada generator bertujuan untuk mengetahui nilai tegangan output yang dihasilkan generator. Pengukuran tegangan output dilakukan pada masing masing posisi nozzle dengan sudut nozzle yang menghasilkan RPM tertinggi. Dengan didapatkannya nilai dari tegangandan arus output per masing-masing posisi nozzle maka akan dapat ditentukan besarnya daya keluaran dari generator.

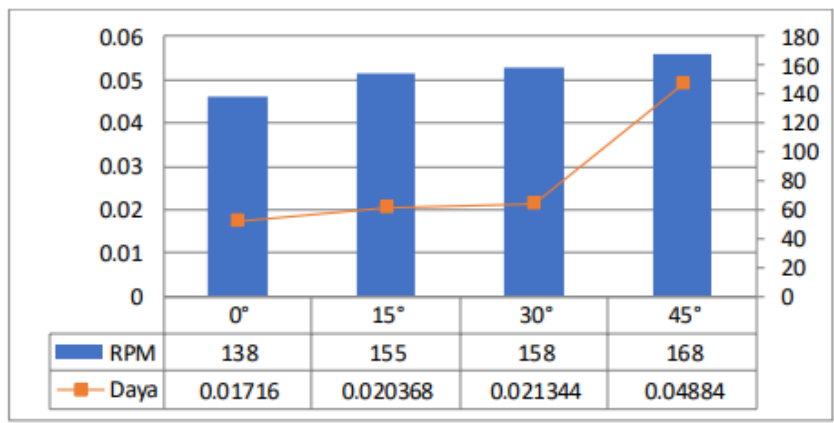

Gambar 5 Pengaruh rpm pada Daya Output Turbin Setengah Lingkaran

Gambar 5 menunjukan peningkatan kecepatan putaran turbin (rpm) berbanding lurus dengan besarnya daya output yang dihasilkan. Semakin cepat putaran turbin (rpm) yang dihasilkan sebuah kincir maka putaran generator juga akan semakin cepat, sehingga daya output yang dihasilkan juga akan semakin besar. Dari keseluruhan data yang didapatkan, dapat dilihat bahwa daya output tertinggi adalah pada posisi nozzle $45^{\circ}$ dengan putaran kincir $168 \mathrm{rpm}$ menghasilkan daya $0.0488 \mathrm{VA}$.

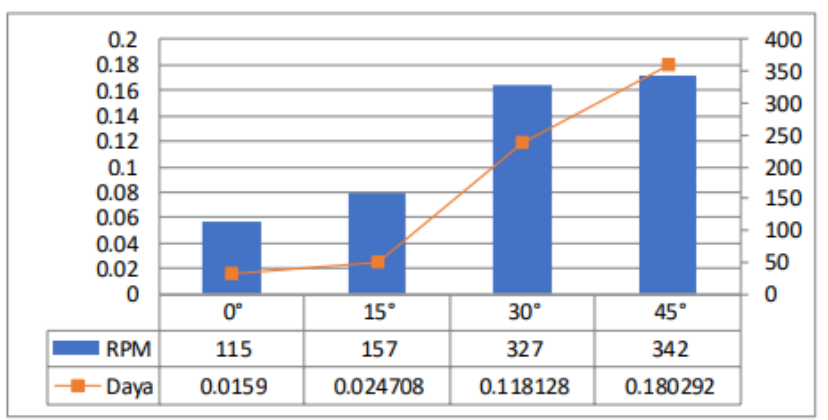

Gambar 6 Pengaruh rpm pada Daya Output Turbin NEST LIE.

Gambar 6 menunjukan peningkatan besarnya rpm berbanding lurus dengan besarnya daya output yang dihasilkan. Dari keseluruhan data yang didapatkan dapat dilihat bahwa daya output tertinggi adalah pada posisi nozzle $45^{\circ}$ dengan putaran kincir $342 \mathrm{rpm}$ menghasilkan daya 0.1802 VA. Berdasarkan hasil rpm dan daya output yang telah didapatkan maka dapat disimpulkan bahwa turbin NEST LIE 
menghasilkan rata- rata rpm dan daya output yang lebih besar dibandingkan dengan turbin setangah lingkaran pada kondisi debit air yang sama, hal ini juga menunjukan bahwa turbin jenis NEST LIE lebih efisien dibandingkan dengan turbin setangah lingkaran.

\section{Perbandingan Kecepatan Putaran Turbin NESTLIE dan Turbin Setengah Lingkaran}

Berdasarkan hasil pengukuran maka dapat dibandingkan kecepatan putaran turbin dan generator turbin NEST LIE dan turbin setengah lingkaran sebagai berikut :

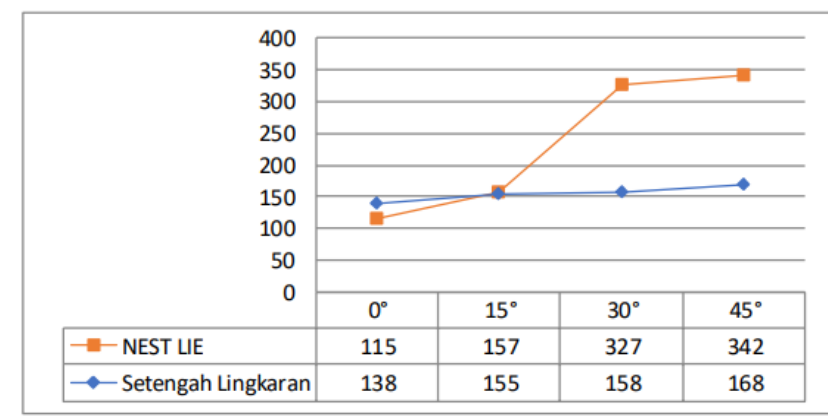

Gambar 7 Perbandingan Kecepatan Turbin NEST-LIE dan Setengah Lingkaran

Pada Gambar 7 dapat dilihat bahwa turbin setengah lingkaran menghasilkan putaran kincir yang lebih besar dibandingkan dengan turbin NEST-LIE pada sudut nozzle $0^{\circ}$, sedangkan pada sudut nozzle $15^{\circ}, 30^{\circ}$ dan $45^{\circ}$ turbin NESTLIE menghasilkan kecepatan putaran turbin yang lebih tinggi. Secara keseluruhan apabila dilihat dari nilai kecepatan putaran tertinggi maka turbin NEST-LIE lebih optimal dalam menghasilkan kecepatan putaran turbin. Hal ini dapat dilihat dari kecepatan putaran maksimum yang dicapai masingmasing turbin, turbin setengah lingkaran mencapai kecepatan putaran maksimum pada $168 \mathrm{rpm}$ sedangkan turbin NESTLIE menghasilkan kecepatan putaran maksimum pada 342 rpm pada sudut nozzle $45^{\circ}$.

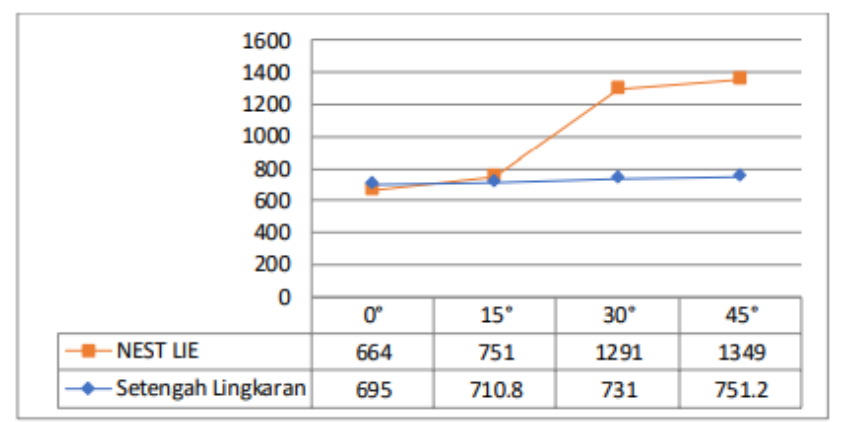

Gambar 8 Perbandingan Kecepatan Putaran Generator NEST-LIE dan Setengah Lingkaran

Pada Gambar 8 dapat dilihat bahwa turbin setengah lingkaran menghasilkan putaran generator yang lebih besar dibandingkan dengan turbin NEST-LIE pada sudut nozzle $0^{\circ}$, sedangkan pada sudut nozzle $15^{\circ}, 30^{\circ}$ dan $45^{\circ}$ turbin NESTLIE menghasilkan kecepatan putaran generator yang lebih tinggi. Secara keseluruhan apabila dilihat dari nilai kecepatan putaran tertinggi maka turbin NEST-LIE lebih optimal dalam menghasilkan kecepatan putaran generator dibandingkan dengan turbin setengah lingkaran. Hal ini dapat dilihat dari kecepatan putaran maksimum yang dicapai masing-masing turbin, turbin setengah lingkaran mencapai kecepatan putaran maksimum generator pada 751,1 rpm sedangkan turbin NEST-LIE menghasilkan kecepatan putaran maksimum pada $1349 \mathrm{rpm}$ pada sudut nozzle $45^{\circ}$.

\section{E. Perbandingan Torsi Turbin NEST-LIE dan Turbin Setengah Lingkaran}

Perbandingan turbin NEST-LIE dan turbin setengah lingkaran dapat dibandingkan berdasarkan nilai torsi yang dihasilkan masing masing turbin. Torsi pada turbin merupakan bentuk ekivalen dari gaya linear yang dihasilkan turbin. Torsi pada turbin menentukan berapa besar gaya yang dihasilkan turbin untuk memutar generator yang dikopel pada turbin. Perhitungan nilai torsi pada kincir dapat dihitung menggunakan data-data hasil pengujian yaitu putaran turbin, putaran generator, tegangan dan arus output dan daya yang dihasilkan generator. Dari data yang didapatkan maka torsi turbin dapat dihitung sebagai berikut:

TABEL 3

PERHITUNGAN TORSI PADA TURBIN SETENGAH LINGKARAN

\begin{tabular}{|c|c|c|c|c|}
\hline $\begin{array}{c}\text { Posisi } \\
\text { Nozzle }\end{array}$ & $\begin{array}{c}\text { Sudut } \\
\text { Nozzle }\end{array}$ & $\begin{array}{c}\text { Putaran } \\
\text { Kincir (rpm) }\end{array}$ & $\begin{array}{c}\text { Daya } \text { output } \\
(\mathrm{VA})\end{array}$ & $\begin{array}{c}\text { Torsi } \\
(\mathrm{Nm})\end{array}$ \\
\hline $0^{\circ}$ & $20^{\circ}$ & 138 & 0.01716 & 0.001188 \\
\hline $15^{\circ}$ & $15^{\circ}$ & 155 & 0.02030 & 0.001250 \\
\hline $30^{\circ}$ & $5^{\circ}$ & 158.8 & 0.02130 & 0.001280 \\
\hline $45^{\circ}$ & $10^{\circ}$ & 168.6 & 0.02130 & 0.002760 \\
\hline
\end{tabular}

Berdasarkan hasil perhitungan torsi turbin sudu setengah lingkaran maka dapat dilihat bahwa karakteristik kinerja turbin sudu setengah lingkaran menghasilkan torsi tertinggi pada posisi nozzle $45^{\circ}$ dan sudut nozzle $10^{\circ}$ dengan torsi sebsesar $0.00276 \mathrm{Nm}$.

TABEL 4

PERHITUNGAN TORSI PADA TURBIN NEST-LIE

\begin{tabular}{|c|c|c|c|c|}
\hline $\begin{array}{c}\text { Posisi } \\
\text { Nozzle }\end{array}$ & $\begin{array}{c}\text { Sudut } \\
\text { Nozzle }\end{array}$ & $\begin{array}{c}\text { Putaran } \\
\text { Kincir (rpm) }\end{array}$ & $\begin{array}{c}\text { Daya } \text { output } \\
(\mathrm{VA})\end{array}$ & $\begin{array}{c}\text { Torsi } \\
(\mathrm{Nm})\end{array}$ \\
\hline $0^{\circ}$ & $20^{\circ}$ & 115.2 & 0.01596 & 0.001326 \\
\hline $15^{\circ}$ & $10^{\circ}$ & 157.1 & 0.0247 & 0.001502 \\
\hline $30^{\circ}$ & $10^{\circ}$ & 327.8 & 0.1181 & 0.003440 \\
\hline $45^{\circ}$ & $5^{\circ}$ & 342.4 & 0.1802 & 0.005030 \\
\hline
\end{tabular}

Berdasarkan hasil perhitungan torsi turbin NEST-LIE maka dapat dilihat bahwa karakteristik kinerja turbin menghasilkan torsi tertinggi pada posisi nozzle $45^{\circ}$ dan sudut nozzle $5^{0}$ dengan torsi yang dihasilkan sebesar $0.00503 \mathrm{Nm}$.

Nia Paramitha : Perbandingan Karakteristik Kinerja Sudu......... 


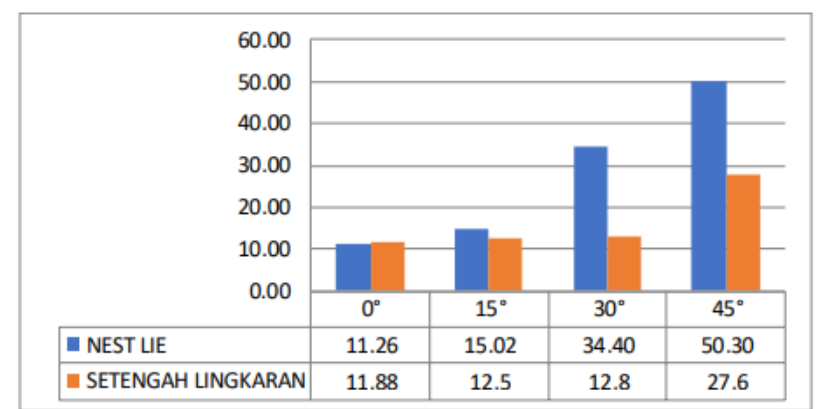

Gambar 9 Perbandingan Torsi turbin NEST-LIE dan Turbin Setengah Lingkaran dalam satuan $\mathrm{Nm}\left(10^{-4}\right)$

Pada Gambar 9 dapat dilihat perbandingan besarnya nilai torsi yang dihasilkan turbin NEST-LIE dan turbin setengah lingkaran pada posisi nozzle $0^{0}, 15^{\circ}, 30^{\circ}$, dan $45^{\circ}$. Perhitungan nilai torsi didasarkan pada RPM tertinggi yang dihasilkan pada masing-masing posisi nozzle. Dapat dilihat pada grafik, turbin NEST-LIE menghasilkan torsi yang lebih besar dibandingkan dengan turbin setengah lingkaran pada posisi nozzle, $15^{\circ}, 30^{\circ}$, dan $45^{\circ}$. Sedangkan pada posisi nozzle $0^{\circ}$ turbin setengah lingkaran menghasilkan torsi yang sedikit lebih besar dibandingkan turbin NEST-LIE. Hal ini menunjukan bahwa turbin NEST-LIE lebih efektif dan efisien dibandingkan dengan turbin konvensional sudu setengah lingkaran.

\section{KESIMPULAN}

Berdasarkan hasil pengujian dan pembahasan yang telah dilakukan maka pada penelitian ini didapatkan kesimpulan sebagai berikut :

1. Turbin setengah lingkaran menghasilkan kecepatan putaran turbin dan generator tertinggi di posisi nozzle $45^{\circ}$ dan sudut nozzle $10^{\circ}$, dengan putaran turbin sebesar 168,6 rpm dan putaran generator sebesar 751 rpm. Turbin setengah lingkaran dapat menghasilkan nilai torsi sebesar $0.00276 \mathrm{Nm}$ dan daya output sebesar $0.0213 \mathrm{VA}$.

2. Turbin NEST-LIE menghasilkan kecepatan putaran turbin dan generator tertinggi di posisi nozzle $45^{\circ}$ dan sudut nozzle $5^{0}$, dengan putaran turbin sebesar 342,4 rpm dan putaran generator sebesar $1349 \mathrm{rpm}$. Turbin NEST-LIE menghasilkan nilai torsi sebesar 0.00503 Nm dan daya output sebesar 0.1802 VA.

3. Hal ini menunjukan bahwa turbin NEST-LIE memiliki karakteristik yang lebih baik dibandingkan dengan turbin setengah lingkaran karena dapat menghasilkan kecepatan putaran, torsi, dan daya output lebih besar pada kondisi optimal.

\section{REFERENSI}

[1] Rencana Umum Energi Nasional, PERPRES Republik Indonesia No. 22 Th. 2017

[2] Weking, et al. Modul Simulasi Kontrol Hidro Power Untuk Praktikum Mahasiswa Teknik Elektro Universitas Udayana. 2015.

[3] P.Ardana dan L. Jasa. Pemanfaatan Saluran Irigasi untuk pembangkit Piko Hidro di dusun Pagi Penebel Tabanan. Majalah Ilmiah Teknologi Elektro, v. 15, n. 1, p. 75-78, june 2016.

[4] D. Christiawan, L. Jasa, Y.P. Sudarmojo. Studi Analisis Pengaruh Model Sudu Turbin Terhadap Putaran Pada Pembangkit Listrik Tenaga
Mikro Hidro ( PLTMH ). Majalah Ilmiah Teknologi Elektro, vol. 16, no. 2, p. 104-111, Aug. 2017.

[5] I W.B. Saputra, A.I. Weking, L. Jasa. "Rancang Bangun Pemodelan Pembangkit Listrik Tenaga Mikro Hidro (PLTMH) Menggunakan Kincir Overshot Wheel". Majalah Ilmiah Teknologi Elektro. Vol. 16. No.02 p. 09. 2017.

[6] L. Jasa dan P. Ardana. Disain Turbin Model Nest-Lie Untuk Mikro Hidro. Majalah Ilmiah Teknologi Elektro, [S.1.], v. 17, n. 2, p. 293-298, nov. 2018.

[7] A. Farid dan A. Humam, Uji Kinerja Turbin Mikro Hidro dengan Variasi Jumlah Sudu Berbentuk Setengah Lingkaran. Jurnal Ilmu-ilmu Teknik Mesin : Universitas Widyagama Malang. Vol 10, No 2. 2018.

[8] G. Ruing, A.I. Weking, L. Jasa. Analisis dan Perbandingan Segitiga Kerja: Turbin Sudu Setengah Lingkaran, Sudu Segitiga dan Sudu Sirip Untuk Menghasilkan RPM yang Tertinggi. Jurnal SPEKTRUM. Vol.06. No.02. p12. 2019.

[9] I G.P.A. Mahayana, L. Jasa, I G. N. Janardana. Rancang Bangun Prototype PLTMH dengan Turbin PELTON Sebagai Modul Praktikum. Jurnal SPEKTRUM, [S.1.], v. 7, n. 4, p. 35-45, dec. 2020.

[10] I M.A.T. Saputra, L. Jasa, I W.A. Wijaya. Pengaruh Tekanan Air dan Sudut Nozzle Terhadap Karakteristik Output pada Prototype PLTMH dengan Turbin PELTON. Jurnal SPEKTRUM, v. 7, n. 4, p. 17-26, dec. 2020.

[11] I.B.G.S.P. Bujawan, L. Jasa, I W.A. Wijaya. Karakteristik Kinerja Prototipe Turbin SNAIL-LIE pada Pembangkit Listrik Tenaga Mikro Hidro. Jurnal SPEKTRUM, Vol.7, No.4, P.115-123, Des 2020.

[12] I.B.D.D. Putra, L. Jasa, I W.A.Wijaya. Desain Perbandingan Karakteristik Turbin Snail-Lie 4 Snail dan 8 Snail pada Prototype Pembangkit Listrik Tenaga Mikro Hidro (PLTMH). Jurnal SPEKTRUM, Vol.7 No.4, Pg. 7-16, Des 2020.

[13] I N.W. Mastika, L. Jasa, dan I.B.G. Manuaba. Karakteristik Kinerja Turbin Nest-Lie pada Prototipe Pembangkit Listrik Tenaga Mikro Hidro. Jurnal SPEKTRUM, Vol.7 no.2, Pg 8-15. Des 2020.

[14] L. Jasa. Investigasi sudut Nozzle dan sudut kelengkungan sudu turbin air untuk peningkatan efisiensi mikro hidro. (Disertasi). Surabaya : ITS. 2015.

[15] P.A. Hendarto, "Pemanfaatan pemandian umum untuk pembangkit listrik tenaga mikrohidro (PLTMH) menggunakan kincir tipe overshot". Surakarta : Universitas Muhammadiyah Surakarta. 2012.

[16] H.Y.S.H. Nugroho, M.K. Sallata. "Pembangkit Listrik Tenaga Mikro Hidro (PLTMH)". Andi Offset. 2015

[17] Damastuti, Teknologi Pembangkit Listrik Tenaga Mikro Hidro. Wacana. Volume 8. Mei-juni 1997.

[18] B.J. Sinaga. Perancangan turbin air untuk sistem pembangkit listrik tenaga mikro hidro (Studi kasus Desa Way Gison Kecamatan Sekincau Kabupaten Lampung Barat). J. Sainsdan Inovasi No.5, Vol 1. 2009.

[19] Y.S.S. Putro, P.T. Juwono, P.H. Wicaksono. "Studi Perencanaan Pembangkit Listrik Tenaga Mikro Hidro (PLTMH) Di Sungai Atei Desa Tumbang Atei Kecamatan Sanamang Mantikai Kabupaten Katingan Provinsi Kalimantan Tengah". Malang: Universitas Brawijaya. 2014.

[20] P.C. Wiliam. Hydroelectric Handbook Second Edition. New York : Jhon Wiley \& Sons Inc. 1950. 